\title{
Essay
}

\section{How cool is Nietzsche - an aid to remove the fear of great philosophers}

\author{
H. Ester \\ Radboud Universiteit Nijmegen \\ THE NETHERLANDS \\ E-mail: j.ester@let.ru.nl
}

\section{Abstract \\ How cool is Nietzsche - an aid to remove the fear of great philosophers}

The German philosopher Friedrich Nietzsche (1844-1900) is far more accessible than many of his contemporaries. He has a tremendous sense of humour, plays with words and expressions, and he is not scared of attacking other philosophers like Hegel and Schopenhauer. Nietzsche's use of figures is very significant thanks to the variations of these figures. The result of his style is a sort of inclusiveness towards the reader. Nietzsche seduces the reader to become a member of the select group of chosen thinkers. His central work "Thus spoke Zarathustra", shows this strategy of conquering the reader or listener in a clear way. Nietzsche's courage to ask other philosophers or "Geisteswissenschaftler" what their essence is can encourage us to ask essential questions. However, Nietzsche's central value of life is too vague to be acceptable and caused a lot of political confusion during the previous century.

\section{Opsomming}

Hoe "cool" is Nietzsche - 'n hulpmiddel om die vrees vir groot filosowe te oorkom

Die Duitse filosoof Friedrich Nietzsche (1844-1900) is meer toeganklik as baie van sy tydgenote. Nietzsche beskik oor 'n geweldige sin vir humor, hy speel met woorde en uitdrukkings, en hy huiwer nie om ander filosowe soos Hegel en Schopen- 
hauer aan te val nie. Nietzsche se gebruik van beelde en metafore is besonder opvallend danksy die variasies van hierdie beelde. Die resultaat van sy styl is 'n vorm van inklusiwiteit na die leser toe. Nietzsche verlei die leser om lid te word van 'n geselekteerde groep denkers. Sy sentrale werk "Aldus het Zarathustra gepraat", toon sy strategie van verowering van die leser of luisteraar op 'n duidelike manier aan. Nietzsche se moed om ander denkers en geesteswetenskaplikes ("Geisteswissenschaftler") te vra wat hulle essensie is, kan ons aanmoedig om belangrike vrae te stel. Sy sentrale waarde vir die lewe is egter te vaag om te aanvaar en het tydens die vorige eeu baie politieke verwarring gesaai.

\section{Introduction}

During my stay in Grahamstown in 2008, I had the opportunity to discuss with colleagues of various departments the necessity that our students and us read the writings of philosophers and theorists in the original. If we do not read the original texts, we only rely on second- or third-hand knowledge. This is an enormous responsibility for all of us. We cannot say that, for example, Jacob Burckhardt is outdated and that there is no use in reading and studying his book on the culture of the Renaissance in Italy. On the contrary, as Peter Burke said: "We will have to go back to Burckhardt in order to study cultural history in the right way." (Burke, 2006:101-103.) My experience as a teacher has taught me that appropriating the tradition of thinking can be a real barrier for students. For them (and for their teachers), Nietzsche is a wonderful scaffold for reaching the desired level of communicating with the past and reflecting on its values. The aim of my article is not to present a contribution to the immense literature on Nietzsche. Its aim is rather to encourage reading Nietzsche, to be charmed and intellectually encouraged by his style, and to be invited to agree and to disagree with him.

\section{The neglect of the original sources}

What happens in our present culture and especially within the field of Humanities - the neglect of the original - is exactly the general practice as far as the work of Nietzsche is concerned. Even a book like The essential Nietzsche (Nietzsche, 2006) confirms this attitude. There is no other philosopher whose work is so often quoted as Nietzsche, be it the Zarathustra (1883-1885) (the work on the origin of our moral values), the Antichrist (1895), or Ecce Homo (1908). We may have the illusion that we do not have to read the complete text, but this really is an illusion. Everything Nietzsche writes is tied 
to other parts of his texts - with certain words, metaphors, with a specific rhythm, and with the special quotations he himself chooses. We reduce the meaning of his work by only quoting him, especially if we do so from summaries or abridgements only. That is what his Italian editors Colli and Montinari mean when they say that it should be forbidden to quote Nietzsche (Nietzsche, 1999a:introd.)

The same fear of quoting Nietzsche can be read in the correspondence between Michel Houellebecque and Bernard-Henri Lévy which was published in 2008. However, in spite of their own warning they go on quoting Nietzsche. If you do not know the sources they quote from, you will not understand what they mean. It is so easy to say "As Nietzsche said" or: "In the words of Nietzsche" (Houellebecq \& Lévy, 2008).

\section{The immortal Friedrich Nietzsche}

There is no other philosopher who as consequently attacked all the certainties of his time as Nietzsche had done. One would expect that the effect of his texts would have ended with the disappearance of their social, political, scientific and religious context. What happened is contrary to the fading away of the transience of his arguments. In fact, it is particularly amazing that this philosopher inspired such important cultural movements as Naturalism, Jugendstil (Art Nouveau), Symbolism, Expressionism, Neue Sachlichkeit (New Objectivity), Modernism, Nazism, Postmodernism, and Post-Postmodernism. Nietzsche is immortal. The leaders of the Allied Countries during the Second World War were wrong when they declared Prussia dead and condemned Nietzsche as the philosopher of the Third Reich. Nietzsche's influence extends far beyond the Third Reich.

For the enormous reception of his work from the seventies during the nineteenth century until today, Nietzsche himself is partly responsible. Or to put it in a more positive way: the astonishing rhetoric quality of his work makes us listen and read him even now. It starts with listening, even while you are reading. Reading Nietzsche leads to an acoustic effect. His work has an oral quality. Nietzsche never tells or writes in abstract terms. He uses images and metaphors to explain what he wants to tell on an abstract level. By doing so, he creates the pleasant feeling that we understand him and that we are the people he has elected to understand him. That intimacy takes place in all his writings when he starts speaking about the world and about the things that are wrong in that world, and then goes on to talk about "us". We are the happy few who understand 
what he wants to say. We belong to the promising generation of honesty; we belong to the absolute word that is central in all Nietzsche's writings: LIFE. Nietzsche appeals to our cultural pride, because we fall for his game of disguised quoting. We recognise and understand, we are part of his game. Humour is part of his game as well, especially humour based on language games. If you understand his refined and delicate play of words, you are his disciple. That is what he wants. He is very seductive.

\section{Style as seduction}

It is about time to demonstrate this with some quotations. But I must be careful to avoid the very mistake I warned you against. To avoid that mistake I will quote the introductions or the first chapters of a number of works. Nietzsche's Zur Genealogie der Moral (1887) starts with:

We do not know ourselves, we the people of knowledge, we ourselves do not know ourselves: there is a good reason for that. We never looked for ourselves. Correctly it was said [by Christ!]: Where your treasure is, there is your heart. Our treasure is where the hives of our knowledge are. We are always on the road as born flying beings and honey collectors of the mind, we only whole-heartedly want to bring something home. Where life is concerned, the so-called experiences: which one of us was serious enough for that, or, who had time enough? In these matters our thoughts were scattered. Our heart is not there. And neither is our ear. The clock has struck twelve. We wake up and ask: what did the clock strike? What have we experienced? And even more: who are we? (Nietzsche, 1999a:247; translation - HE.) ${ }^{1}$

The following quotation is from the first chapter of The birth of tragedy out of the spirit of music (1872):

We shall have gained much for the science of aesthetics, once we have perceived not only by logical inference, but by the immediate certainty of intuition, that the continuous development of art is bound up with the duplexity of the Apollonian and the Dionysian: in like manner procreation is dependent on the duality of the sexes, involving perpetual conflicts with only

1 The reason why I made all the translations myself lies in the challenge to translate a very individual German text into a different language. 
periodically intervening reconciliations. (Nietzsche, 2006:127 \& 1999b:248-249.)

\section{Towards the dialogue}

It is time for a first conclusion. If you start studying cultural history, it may feel like a burden to realise that you will have to study and read so many predecessors whom you cannot neglect. They have thought before you and on your behalf. Your intellectual integrity tells you to listen to them and to talk to them. The first thing is: to listen. The negative effect of this is that the dialogue you are longing for can only start after an exhausting period of being a passive listener. In the case of Nietzsche, listening to him is learning and activating your own capacity of reflection. His work is based on a continuous dialogue with human thinking from Plato to Ranke or Baudelaire. If you, or, if we read Nietzsche, we acquire a solid basis for understanding him and we get the courage to read what he has read, because we know that we are dealing with philosophers and their assailable assumptions. Anecdotes play an important role in Nietzsche's works. They have to be handled with care. But, if Nietzsche's discussion with others is based on their real ideas, he gives us a first opening to understand them as well. Here lies one of the many valuable elements of Nietzsche's work. However, it is not the most essential value for the humanities.

\section{Space for reflection on ourselves}

The essential meaning of Nietzsche's work lies in his power to lift us from our daily duties and the accepted morals of the work we do in research and education, to the higher level of asking profound questions about the ethos, the aims, as well as the personal and social consequences of what we do. To demonstrate this, I will focus on one of Nietzsche's early works. It was published in 1874 as one of his four Unzeitgemässe Betrachtungen, his untimely reflections/meditations like the essay "About the use and disadvantage of historical knowledge for life". What does Nietzsche tell us in this essay? As we already know from his style, he starts with an image and a story. The essay starts with:

Look at the herd that grazes and passes by. This herd does not know what yesterday is, what today is. It jumps around, it eats, it rests, it chews the cud, it jumps again and so from the early morning until the night, from day to day. They are short with everything, with their lust and irritation, short with the post of the moment and for that reason neither melancholic nor bored, or 
blasé. It is hard for mankind to see this, because of the fact that mankind is proud of being man in comparison with the animal. And still man looks jealously upon the happiness of the animal. That is what man wants: to live like an animal, not bored and not under pain. And he wants it in vain, because he is not like an animal. Man asks the animal from time to time: why don't you talk to me about your happiness and why do you only look at me. The animal would like to answer and to say: it comes because I forget immediately what I wanted to say. And then he forgets this answer as well and is silent so that man is amazed because of this. Man is astonished about his inability to forget and his continuous hanging on to the past. The chain goes with him. The burden of the past is always there. That is the reason why man, watching the herd or in his near surroundings watching the child, it moves him, it touches him. Because the child has no past to renounce. The child plays between the fences of the past and the present in blissful blindness. But soon this game will be interrupted. Too soon he will be called away from oblivion. Then the child learns to know the word: it was. That catchword with which battling, suffering and boring come near to mankind. This word reminds him what his existence is: a simple past which can never be completed. The conclusion is: there is a grade of sleeplessness, of ruminating, of historical sense, which the lively comes to, suffers damage and perishes, be it an individual human being, a nation or a culture. The answer is that the unhistorical is equally necessary for the health of an individual, of a nation and of a culture. (Nietzsche, 1999c:248-249; translation - HE.)

\section{Antiquarian, monumental, critical}

Three ways of dealing with history are essential: the antiquarian way, the monumental way, and the critical way. They all have their function. Let me briefly explain the way Nietzsche discusses the problem of historical knowledge with us, the problem of dealing with history and memory. Nietzsche states that the unhistorical and the historical are equally necessary to the health of an individual, a community and a culture. The monumental way returns to the great moments of history in order to give inspiration to the man of action. The antiquarian way preserves what has survived from ancient days. Respect is the keyword. And then there is the third way:

This is the 'critical' way; which is also in the service of life. Man must have the strength to break up the past; and apply it too, in order to live. He must bring the past to the bar of judgement, interrogate it remorselessly, and finally condemn it. Every past is worth condemning: this is the rule in mortal affairs, which 
always contain a large measure of human power and human weakness. (Nietzsche, 1999c:269.)

This untimely reflection/meditation represents Nietzsche's way of thinking. If we can see something valuable in it, we can look for more. To make it a bit easier for us to understand the implication of Nietzsche's way of rethinking and re-evaluation, we will have a look at the book Ecce Homo, of which the title is almost wicked because of the identification of Nietzsche with Jesus Christ (cf. John, 19:5, where Pontius Pilate uses these words. In the English translation he says: "Behold the man"). In Ecce Homo Nietzsche presents his historical message in a grotesque way. It is not the book we should read when we first want to know Nietzsche. But it is valuable because in it Nietzsche recapitulates the essential meaning of his writings. Certainly we must laugh when he praises his Zarathustra as a prophetical work for the coming thousand years of human history. I refer to Ecce Homo because of what Nietzsche says in it about the untimely reflection/meditation we are discussing. Now we see that his criticism has a much wider perspective. Now we see clearly that what Nietzsche says about the study of history is applicable to the humanities as a whole. His criticism is not limited to the academic world only. It includes the social world, and the world of industrial production which is at stake here. Let me quote the essential part of his argument:

The second untimely reflection brings the dangerous, the lifegnawing and life-poisoning in our way of practicing science and the Humanities into the light. It shows that life is sick from this inhuman machinery and mechanism. The essay shows the impersonality of the labourer, the false economy of the 'division of labour' [according to Adam Smith in his The wealth of nations]. The aim gets lost, culture becomes barbaric. In this essay the historical sense, of which this country is proud, is regarded as an illness, as typical sign of decadence. And this was seen for the very first time. (Nietzsche, 1999d:316; translation - HE.)

\section{The truth of life}

Nietzsche makes us aware of the choices we make before we really think, before we begin to understand. He puts the emphasis on our own choice in wanting to understand. Within this framework, Nietzsche stresses that thinking and reflection are always relative. They rely on assumptions, suppositions that have already been made. Yes, seen from this point of view, Nietzsche is a predecessor of the philosophy in which truth is regarded to be part of the linguistic 
construction that covers the world and gives us the illusion of power, understanding, and domination. Here we can see to what extent Michel Foucault was inspired by Nietzsche. But it would be absolutely wrong to stop here. Nietzsche is not criticising the frameworks of thinking on the basis of the absence of truth or the impossibility of reaching the truth. In that case, he would have been like Pontius Pilate. No, his entire philosophy is constructed on the primary idea or prerequisite that Life is the judging value, that the criterion for judgement is the justification of Life. What is this Life in Nietzsche's view? He has dealt with this notion in all his works. It is the absolute centre, it is the overwhelming power of his philosophy. I again refer to Ecce Homo in which Nietzsche says the following:

This last, happiest, overwhelming reckless Yes to life is not only the highest, but it is also the deepest understanding, the understanding which truth and science [Wissenschaft] strictly confirm and keep alive. [...] The aspects of life that are rejected by Christians and other nihilists are even infinitely higher in the ranking of values than that what the décadence-instinct has approved, was allowed to approve [gut heissen durfte]. To understand this, you need courage as its condition, a surplus of power, because, as far as courage is allowed to venture according to the degree of power, one approaches the truth. The insight, the saying Yes to reality, is as necessary for the strong as is cowardice and escape from reality for the weak and their so-called 'ideal'. (Nietzsche, 1999d:311-312; translation HE.)

\section{Conclusion}

In short, according to Nietzsche the final notion is that you should accept life, even that you should affirm it and that you should be willing to live it again. An absolute loyalty to life, to your life. Here, many questions arise. There is no clear answer to the question about life. This may be the reason why Life for example in the period of Expressionism became such an unexamined slogan. Nevertheless, with his radical thoughts Nietzsche teaches us to think about life and about the truth of life. For us, I think, he is important as the man who questioned our premature truths. Too often in history he has been seen as a prophet, as man of answers. I would argue that he is, and always will be the man of vital questions.

\section{List of References}

BURKE, P. 2006. What is cultural history? Cambridge: Cambridge University Press. 
HOUELLEBECQ, M. \& LEVY, B-H. 2008. Ennemis publics. Paris: Flammarion \& Grasset.

NIETZSCHE, F. 1999a. Zur Genealogie der Moral. (In Nietzsche, F. Kritische Studiengabe. Hrsg. von Giorgio Colli \& Mazzino Montinari. Berlin: De Gruyter.) (KSA, Band 5.)

NIETZSCHE, F. 1999b. Die Geburt der Tragödie aus dem Geiste der Musik. (In Nietzsche, F. Kritische Studienausgabe. Hrsg. von Giorgio Colli \& Mazzino Montinari. Berlin: De Gruyter.) (KSA, Band 1.)

NIETZSCHE, F. 1999c. Unzeitgemäße Betrachtungen 2. (In Nietzsche, F. Kritische Studienausgabe. Hrsg. von Giorgio Colli \& Mazzino Montinari. Berlin: De Gruyter.) (KSA, Band 1.)

NIETZSCHE, F. 1999d. Ecce Homo. (In Nietzsche, F. Kritische Studienausgabe. Hrsg. von Giorgio Colli \& Mazzino Montinari. Berlin: De Gruyter.) (KSA, Band 6.)

NIETZSCHE, F. 2006 [1939]. The essential Nietzsche. Ed. by H. Mann. Mineola: Dover Publications.

\section{Key concepts:}

life, dangerous concept of philosophy as dialogue

seduction, style as

thinking, presuppositions of

vitalism

\section{Kernbegrippe:}

dink, vooronderstellings van

lewe, gevaarlik konsep van

verleidingstyl

vitalisme

wysbegeerte as dialoog 
